\title{
Synthesis of galactofuranose-containing disaccharides using thioimidoyl-type donors
}

\author{
Ronan Euzen, ${ }^{\dagger}$ Vincent Ferrières* and Daniel Plusquellec \\ Ecole Nationale Supérieure de Chimie de Rennes, UMR CNRS 6226, Avenue du Général Leclerc, F-35700 Rennes, France \\ Received 21 July 2006; received in revised form 28 September 2006; accepted 2 October 2006 \\ Available online 7 October 2006
}

\begin{abstract}
Four galactofuranose-containing disaccharides have been prepared utilising various thioimidates $\left[\mathrm{Gal} f-\mathrm{SC}(=\mathrm{NR}) \mathrm{XR}{ }^{\prime}\right]$ and suitably protected acceptors as key precursors. We observed that the efficiency of the coupling reactions was particularly dependent on the aglycon present on the furanosyl donor when copper(II) ions were used as the promoter, and that activation could be correlated with the nature of the third heteroatom, $\mathrm{X}$.
\end{abstract}

(c) 2006 Elsevier Ltd. All rights reserved.

Keywords: Galactofuranose-containing disaccharides; Glycosylation reactions; Thioimidates

\section{Introduction}

In mammalian biomolecules, hexoses are exclusively found in the pyranose form. Nevertheless, numerous efforts in the structural elucidation of compounds isolated from various microorganisms have clearly established the presence of hexofuranosides in some oligo- and polysaccharides. ${ }^{1-4}$ Consequently, it is legitimate to wonder about the gain for such organisms to biosynthesize hexofuranose-containing glycoconjugates considering that furanosides are generally less stable than their pyranosidic counterparts. ${ }^{5}$ Moreover, many of these microorganisms are pathogenic; however, the role of hexofuranosides in the development of diseases and/or the way in which they interact with receptors are not yet clearly elucidated. ${ }^{6}$ Because mammalian cells are devoid of the ability to biosynthesize and/or to metabolize glycofuranosides, such molecules are of great interest to increase knowledge relating to their biological and physicochemical roles, and the biological mechanisms connected with them. This observation favourably argues

\footnotetext{
* Corresponding author. Tel.: +33 223238 058; fax: +33 223238 046; e-mail: vincent.ferrieres@ensc-rennes.fr

${ }^{\dagger}$ Present address: University of Bern, Department of Chemistry and Biochemistry, Freiestrasse 3, 3012 Bern, Switzerland.
}

for the increasing attention that has been paid to new chemical syntheses of oligofuranosides of varying complexities. $^{6-15}$

Among hexoses present in a furanose form, three natural conjugates have been found containing D-glucose $(\mathrm{D}-\mathrm{Glc})^{16-18}$ and one with D-mannose (D-Man). ${ }^{19}$ However, D-fucose (D-Fuc), ${ }^{20,21}$ (not $\mathrm{L}$ as in mammalian cells) and D-galactose (D-Gal) are the most widely distributed. The $\mathrm{D}-\mathrm{Gal} f$ residue (Table 1 ) can be connected either to pyranosyl units, that is, D-Man $p,{ }^{22,23} \mathrm{D}$ Glc $p,{ }^{24,25}$ D-Gal $p,{ }^{21} N$-acetyl-D-galactosamine (D-Gal $p$ NAc) ${ }^{26-28}$ or glucosamine (D-GlcpNAc), ${ }^{29}$ L-rhamnose (L-Rhap), ${ }^{30-32}$ D-fructose (D-Frup $)^{33}$ or to galactofuranosyl entities. ${ }^{29,34,35,23}$ Among these natural products, most of the Gal $f$ units are connected with their aglycon through $\beta$-D- $(1 \rightarrow 6)$ or $\beta$-D- $(1 \rightarrow 5)$ linkages (Table 1$)$.

In this context, and considering our interest in the preparation of hexofuranose-containing derivatives, ${ }^{9-11}$ disaccharides 1-4 were selected as targets of biological interest (Fig. 1). The sequence $\beta$-D-Gal $f-(1 \rightarrow 6)-\alpha$-D-Glc $p$ as in $\mathbf{1}$ is a subunit of the $\mathrm{O}$-antigenic glycoside produced by the K-12 strain of Escherichia coli, ${ }^{24}$ a bacteria that has been commonly used for genetic studies. The second saccharidic structure $\beta$-D-Gal $f-(1 \rightarrow 6)-\alpha$-D-Man $p$, which alternatively presents furanosyl and pyranosyl entities (2) was designed as a building block for further 
Table 1. Selection of microorganisms biosynthesizing oligofuranosides

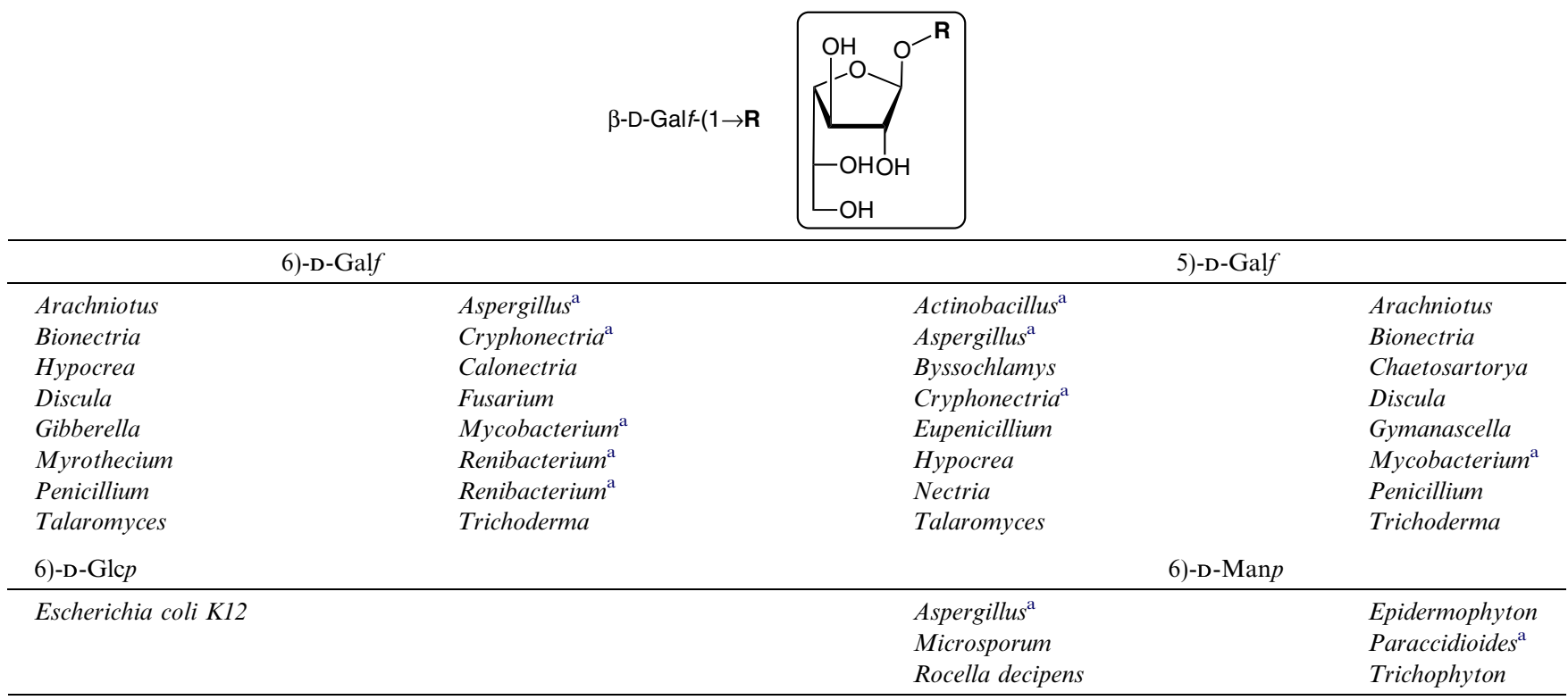

${ }^{\mathrm{a}}$ These microorganisms are potentially pathogenic.
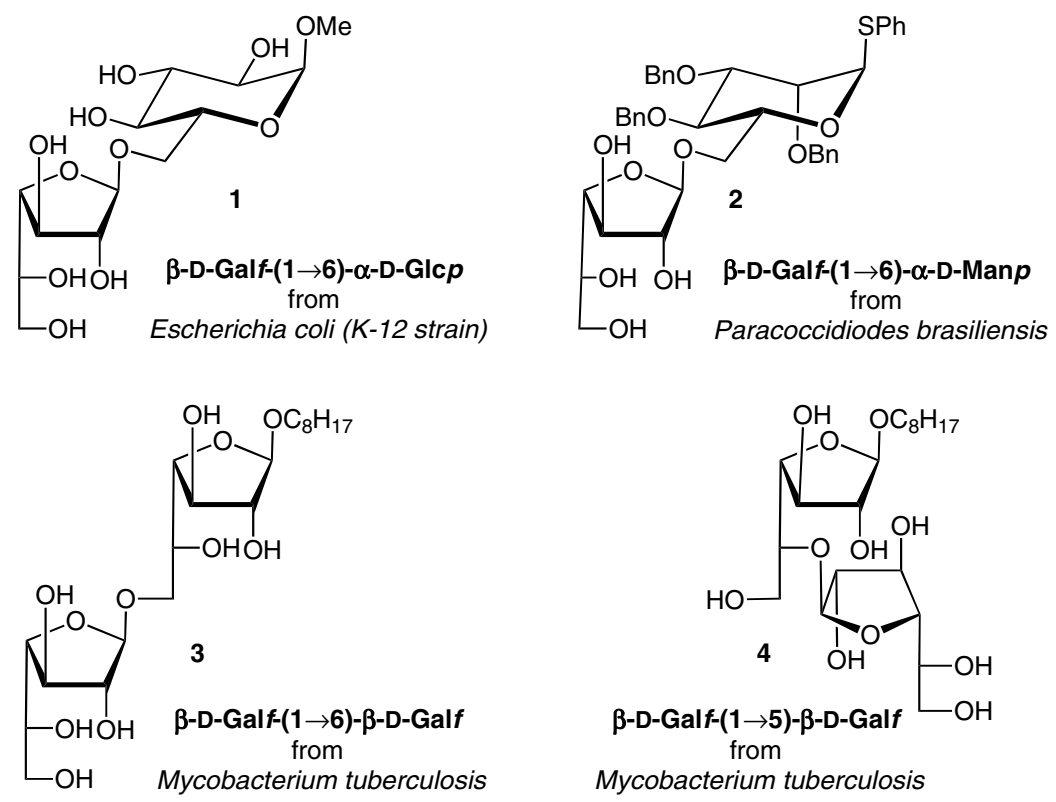

Figure 1. Structure of targeted galactofuranose-containing disaccharides 1-4.

elongation to yield oligosaccharides found in Paracoccidioides brasiliensis. ${ }^{36}$ This pathogenic fungus is known to affect the lungs, lymphoid and mucocutaneaous tissues of rural farm workers in South and Central America. The glycosidic parts of digalactofuranosides 3 ( $\beta$-D-Gal $f-(1 \rightarrow 6)-\alpha$-D-Gal $f)$ and 4 ( $\beta$-D-Gal $f-(1 \rightarrow 5)-\alpha-$ $\mathrm{D}-\mathrm{Gal} f$ ) are found in the cell wall that ensures the membrane stability of Mycobacterium tuberculosis, ${ }^{30}$ the lethal bacteria responsible for the death of more than 2 million people each year.

These four disaccharides were also chosen as model compounds to probe the structural effects in glycosyl- ation reactions based on the use of galactofuranosyl thioimidates as furanosyl donors. This family of donors belongs to the thioglycoside-type donors but they potentially differ from more standard thioglycosides because they can be activated by 'remote activation' (Fig. 2). ${ }^{37,38}$

The first outcome of this mechanistic feature is that some differences in the reactivity of the donors can be connected with the structure of the aglycon and/or the nature of the promoter. This is the reason why we have selected thioimidoyl furanosides $\mathbf{5 - 8}$ as donors (Fig. 3). These compounds differ from each other in (i) the nature of the $\mathrm{X}$ group $(\mathrm{X}=\mathrm{NH}$ or $\mathrm{S}$, the latter having 'softer' 


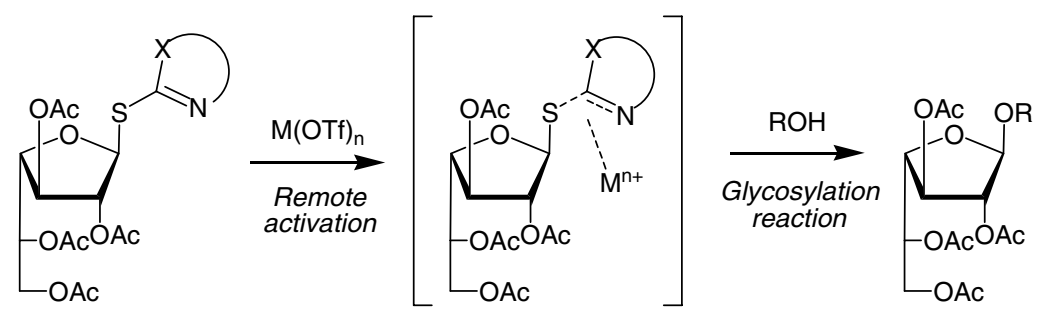

Figure 2. Expected activation of thioimidates.
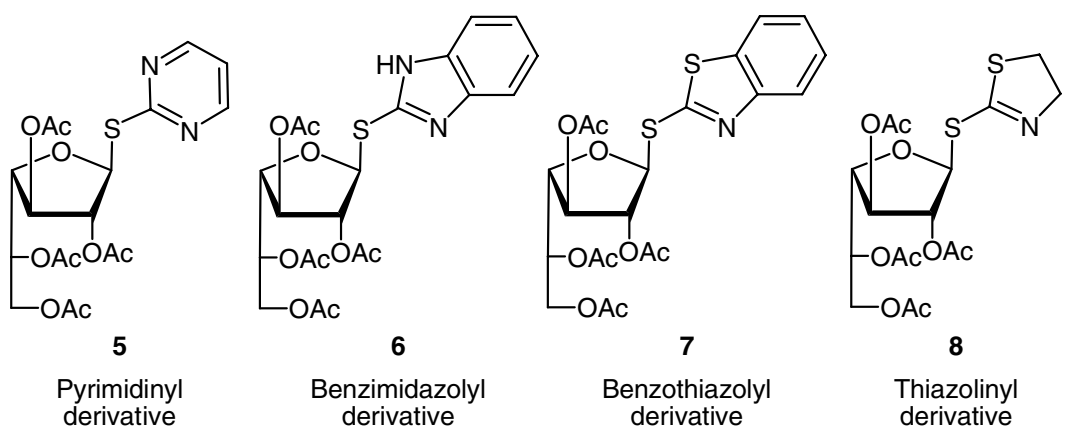

Figure 3. Structure of donors 5-8.

basic properties compared to the amino group, as based upon the HSAB principle), (ii) the basicity of the heterocycle and (iii) the size of the aglycon.

Moreover, because thioimidates are likely to be activated not directly at the anomeric sulfur atom, orthogonality with thioethyl or thiophenyl glycosides can be expected. ${ }^{39,40}$ We describe herein the synthesis of naturally occurring galactofuranose-containing disaccharides and our evaluation of four galactofuranosyl thioimidates in reactions with acceptors of different steric accessibilities, for example, primary versus secondary hydroxyl groups or furanosyl versus pyranosyl entities.

\section{Results and discussion}

To prepare 1,2-trans furanosides 1-4, the $\beta$-directing effect was achieved through the assistance of a 2-O-acetyl protecting group on the galactosyl donor. Consequently, the required galactofuranosides were obtained from peracetylated galactofuranose $(\mathbf{9})^{41}$ according to a Ferrier reaction $^{42}$ catalyzed by the boron trifluoride-etherate complex. Excess catalyst was used to shift the thione/ thiol equilibrium towards the thiol form and to limit the formation of the N-glycoside as a by-product. ${ }^{43}$ Donors $5-7^{44}$ were thus obtained in good to excellent yields (Scheme 1). This synthesis was also extended to the new derivative $\mathbf{8},{ }^{43}$ because the thiazolinyl group was used as the versatile leaving group in 1,2-cis glycosidation reactions of pyranosyl donors. ${ }^{39,45,46}$ In the preparation of compounds 5-8, we observed that the nature of the third heteroatom $\mathrm{X}$ of the thioimidoyl residue influenced the diastereocontrol of the Ferrier reaction. Better ratios favouring the expected $\beta$-anomer were obtained with a nitrogen atom $(\alpha / \beta=0: 1)$ instead of a sulfur $(1: 4.2<$ $\alpha / \beta<1: 6.7)$. Better selectivities were nevertheless observed by reducing the reaction time but this modification also resulted in lower yields. However, owing to the presence of the 2-O-participating group, this parameter was not detrimental for further glycosylation reactions.

On the another hand, acceptors 10-13 (Fig. 4) are known compounds and were prepared as previously described $\left(\mathbf{1 0},{ }^{5,47} \mathbf{1 1},{ }^{48} \mathbf{1 2},{ }^{49} \mathbf{1 3}^{50}\right)$. Nevertheless, an interesting optimization for the synthesis of $\mathbf{1 2}$ was performed. The preparation of the latter began (Scheme 2) with the regioselective tritylation of an anomeric mixture of the well-known octyl galactofuranoside $\mathbf{1 4} \boldsymbol{\alpha}, \boldsymbol{\beta}^{51,52}$ by trityl chloride ( $\left.\mathrm{TrCl}\right)$ in the presence of $N, N$-dimethyl-4-aminopyridine (DMAP). Unfortunately, a disappointing reaction was observed under these conditions (yields lower than $5 \%$ ). To overcome this limitation, the desired etherification was performed

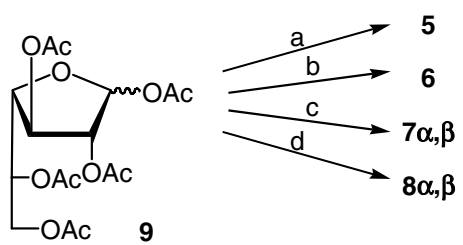

Scheme 1. Synthesis of thioimidates 5-8. Reagents and conditions: (a) $(99 \%, \alpha / \beta=0: 1) ;{ }^{44}$ (b) $(91 \%, \alpha / \beta=0: 1) ;{ }^{44}$ (c) $(83 \%, \alpha / \beta=1: 6.7) ;{ }^{44}$ (d) 2-mercaptothiazoline, $\mathrm{BF}_{3} \cdot \mathrm{OEt}_{2}(93 \%, \alpha / \beta=1: 4.2)$. 


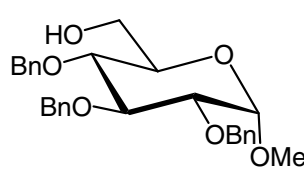

10

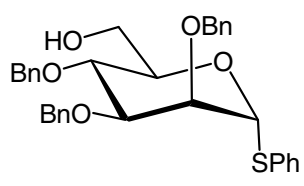

11

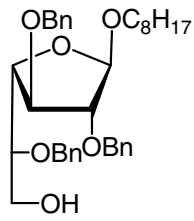

12

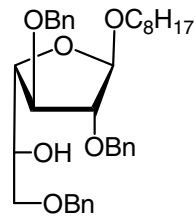

13

Figure 4. Structures of required acceptors 10-13

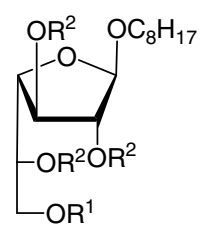

\begin{tabular}{lcc}
\hline & $\mathrm{R}^{1}$ & $\mathrm{R}^{2}$ \\
\hline $14 \beta$ & $\mathrm{H}$ & $\mathrm{H}$ \\
$15 \mathrm{a}$ & $\mathrm{MMTr}$ & $\mathrm{H}$ \\
$15 \mathrm{~b}$ & $\mathrm{Tr}$ & $\mathrm{H}$ \\
16 & $\mathrm{Tr}$ & $\mathrm{Bn})_{\mathrm{b}} \mathrm{c}$ \\
12 & $\mathrm{H}$ & $\mathrm{Bn} 2 \mathrm{~d}$ \\
\hline
\end{tabular}

Scheme 2. Optimized synthesis of acceptor 12. Reagents: (a) MMTrCl, DMAP (64\%); (b) TrCl-DMAP salt (80\%); (c) BnBr, NaH (99\%); (d) $\mathrm{AcOH}, \mathrm{H}_{2} \mathrm{O}(78 \%)$.

from the pure 1,2-trans-furanoside $\mathbf{1 4 \beta}$, which could be selectively crystallized from $\mathbf{1 4} \boldsymbol{\alpha}, \boldsymbol{\beta}$ in diethyl ether. ${ }^{52}$

To explain the apparent inhibition of the Williamson etherification by the 1,2-cis-anomer, we assumed that the standard tritylation reagent was not reactive enough, and more importantly, that the nucleophilic base DMAP could engage in competitive reactions, that is, (i) nucleophilic activation of $\mathrm{TrCl}$ and (ii) possible deprotonation of the more acidic and more hindered 2-hydroxyl function in the 1,2-cis galactoside $\mathbf{1 4} \alpha$. Such a property, which proved to be of particular interest in selective 2-O-protection, ${ }^{53}$ was suspected to be a factor that disfavoured the protection of the primary hydroxyl. On this basis, the introduction of the trityl group was first attempted starting from the pure $\mathbf{1 4 \beta}$ and the more reactive $p$-methoxyphenyldiphenyl chloride (MMTrCl). The target product 15a was then isolated in an increased $64 \%$ yield after only $4 \mathrm{~h}$ at room temperature and chromatographic purification. Secondly, the use of the electrophilic salt previously prepared from trityl chloride and $\mathrm{DMAP}^{54}$ also gave increased performance because after $24 \mathrm{~h}$ at reflux in dichloromethane, the triol 15b was obtained in a good and reproducible $80 \%$ yield on a multi-gram scale $(20 \mathrm{~g})$. Subsequent benzylation of 15b under standard conditions followed by detritylation in aqueous acetic acid afforded the desired compound $\mathbf{1 2}$ in $77 \%$ overall yield. This approach is highly competitive with those proposed by Plusquellec et al. ${ }^{49}$ or Reynolds and co-workers. ${ }^{50}$

For subsequent glycosidation of donors 5-8, we were first interested in synthesizing the $\beta$-D-Gal $f-(1 \rightarrow 6)-\alpha$-DGlc $p$ disaccharide residue found in E. coli (K-12 strain) and particularly focused our attention on the nature of the promoter (Table 2). To ensure selective activation of the thioimidoyl donor, no halonium ion was used as promoter. After experimentation, we observed the disappearance of the donor, thus showing its activation, with the Lewis acids trimethylsilyl trifluoromethanesulfonate (TMSOTf) and copper(II) trifluoromethanesulfonate. These results also showed the significant influence of the nature of the leaving group because the thiazolinyl-type donors 7 and 8 (entries $8-11, \mathrm{X}=\mathrm{S}$ ) demonstrated very poor activity in the glycosylation of $\mathbf{1 0}$ while the desired disaccharide $\mathbf{1 7}$ was isolated in good $58 \%$ and $67 \%$ yield starting from the pyrimidinyl and benzimidazolinyl derivatives $\mathbf{6}(\mathrm{X}=\mathrm{NH})$ and $\mathbf{5}$ $(X=N)$, respectively (entries 2, 4, 5 and 7). Moreover, the most efficient coupling was obtained with the more thiophilic copper(II) salt (entries 1/2, 6/7 and 10/11); adding only one molar equivalent of this promoter resulted in a significantly decreased yield (entries $2 / 3$ ). It is also interesting to note that the modification of the initial equimolar donor/acceptor ratio, whatever the sense, had a positive influence on the yield of the reaction as the desired coupling product $\mathbf{1 7}$ was isolated, after deacetylation under Zemplen transesterification, in $\sim 75 \%$ yield (entries 4 and 5). Further removal of the benzyl groups by hydrogenolysis afforded the target disaccharide 1 in $97 \%$ yield.

This preliminary study allowed us to select the 2-thiopyrimidinyl aglycon as the most appropriate leaving group in O-glycosylation reactions activated by copper(II) triflate. The use of the thiopyrmidinyl donor was further successfully extended to the preparation of the $\beta$-D-Galf-( $1 \rightarrow 6)-\alpha$-D-Man $p$ disaccharide 2 , using thiomannopyranoside 11, which bears a primary hydroxyl, as the acceptor (Scheme 3). The donor 5 thus smoothly reacted with 11 and afforded, after deacetylation and chromatographic purification, the desired disaccharide 2 in $60 \%$ yield.

Subsequently, the preparation of the disaccharides 3 and $\mathbf{4}$, fragments of the glycosidic skeleton of the galactan produced by $M$. tuberculosis, required the use of glycosyl acceptors in a furanose form. These compounds are well known to be very sensitive to conformational changes not only because the five-membered ring is more flexible than the pyranosyl counterpart ${ }^{6}$ but also because the side arm is less constrained, thus increasing the number of possible rotamers. Consequently, this molecular parameter may influence the progress of the glycosylation reaction. Indeed, modest yields were obtained for the synthesis of protected disaccharides $20(30 \%)$ and $21(14 \%)$ (Scheme 4$)$ and the yields could 
Table 2. Model glycosidic coupling for selection of the most appropriate donor

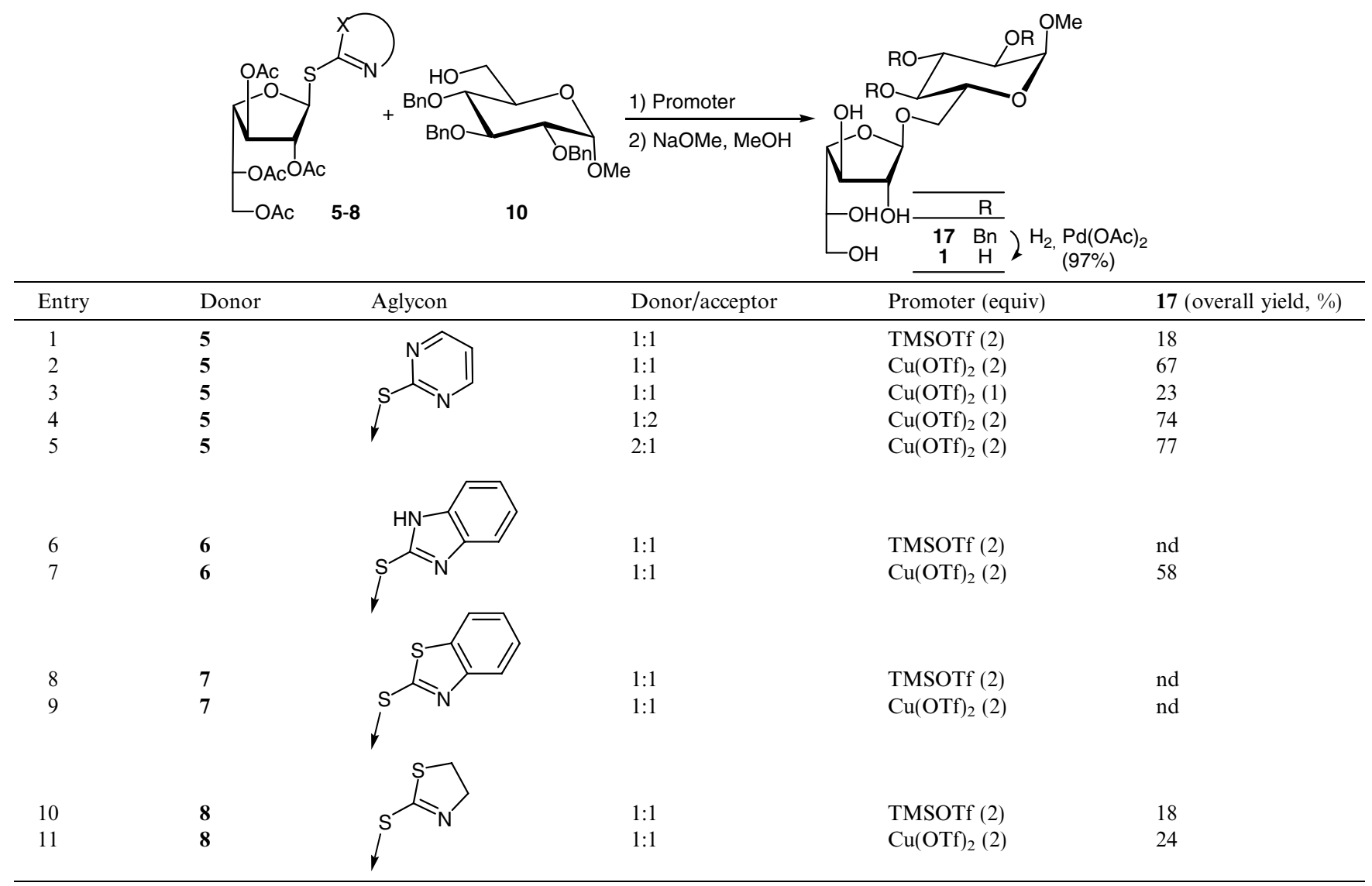

nd: not determined.

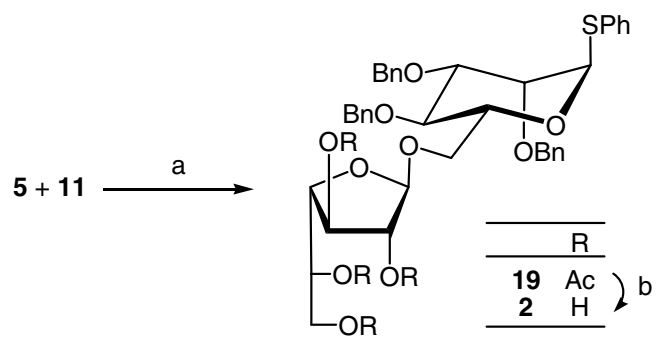

Scheme 3. Orthogonal glycosylation. Reagents: (a) $\mathrm{Cu}(\mathrm{OTf})_{2}$; (b) $\mathrm{NaOMe}, \mathrm{MeOH}(60 \%$ for two steps).

not be improved even with a more standard promoter such as NIS/TMSOTf. A final debenzylation performed in a hydrogen atmosphere catalyzed by palladium(II) acetate afforded $\mathbf{3}$ in good yield.

As expected, the results presented here suggested that the reactions were dependant on the nature of the electrophilic and nucleophilic partners and also on the promoter. We first observed a better reactivity for primary hydroxyl groups and showed that the higher yields of coupling were obtained with pyranosyl acceptors versus furanosyl ones. Secondly, the glycosylation could be achieved due to activation of the donor, that is, interac-

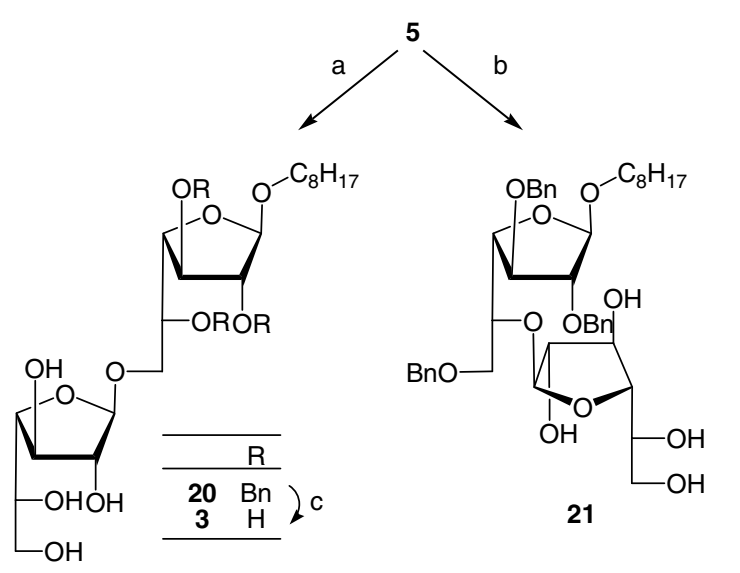

Scheme 4. Synthesis of digalactofuranosides 3 and 21. Reagents: (a) (i) 12, $\mathrm{Cu}(\mathrm{OTf})_{2}$; (ii) $\mathrm{NaOMe}, \mathrm{MeOH}(30 \%$ for two steps); (b) 13, $\mathrm{Cu}(\mathrm{OTf})_{2}$; (ii) $\mathrm{NaOMe}, \mathrm{MeOH}$ (14\% for two steps); (c) $\mathrm{H}_{2}, \mathrm{Pd}(\mathrm{OAc})_{2}$ (3: $67 \%$ for two steps).

tion between the aglycon and the reactive catalytic species, $\mathrm{Cu}^{2+}$. On the basis of the $\mathrm{p} K_{\mathrm{a}}$ of the free aglycons (Table 3 ), the activation process could not be simply ascribed to this parameter because donors $\mathbf{5}$ and $\mathbf{8 \beta}$ have two heterocycles with similar acidity but a significantly 
Table 3. Selected physicochemical properties of donors 5-8

\begin{tabular}{|c|c|c|c|c|c|}
\hline Entry & Donor & Heterocycle & $\mathrm{p} K_{\mathrm{a}}^{\mathrm{a}}$ & $\begin{array}{l}\delta_{\mathrm{H}-1} \\
(\mathrm{ppm})\end{array}$ & $\begin{array}{l}\delta_{\mathrm{C}-1} \\
(\mathrm{ppm})\end{array}$ \\
\hline 1 & 5 & & $1.65^{\mathrm{b}}$ & 6.47 & 87.5 \\
\hline 2 & 6 & & $0.31^{\mathrm{b}}$ & 5.94 & 89.2 \\
\hline 3 & $7 \beta$ & & $-3.17^{\mathrm{b}}$ & 6.27 & 89.3 \\
\hline 4 & $8 \beta$ & & $1.28^{\mathrm{b}}$ & 5.39 & 88.4 \\
\hline
\end{tabular}

${ }^{\mathrm{a}}$ The $\mathrm{p} K_{\mathrm{a}}$ values correspond to the unglycosylated heterocycles.

b $T$ he $\mathrm{p} K_{\mathrm{a}}$ values were obtained from 'calculated properties' for each compound in SciFinder Scholar v.2006.

different reactivity (Table 2 , entries 2 and 11). On the other hand, Hanessian et al. could correlate the high glycosylating ability of MOP hexopyransides to upfield and downfield chemical shifts for ${ }^{1} \mathrm{H}$ and ${ }^{13} \mathrm{C}$, respectively. ${ }^{37}$ Unfortunately, such a correlation could not explain the results observed with thioimidates 5-8 (Table 3).

To rationalize our results, two main sets of experiments, already published, have also to be considered. First, by comparison with the phosphorylation of thioimidates of the same series ${ }^{44}$ for which we had concluded better suitability between phosphoric acid and the benzimidazolyl derivative, it would have been difficult to predict the higher efficiency of the 2-pyrimidinyl thiofuranoside $\mathbf{5}$ in O-glycosylation reactions with saccharide acceptors. Second, it was also very surprising to notice the low reactivity of the disarmed donor $\mathbf{8}$ belonging to the thiazolinyl family, although such donors were presented as an interesting alternative to standard glycosylation using either armed or disarmed thioglycopyranosides as an activator. ${ }^{40,55}$ As a consequence, the nature of the interactions between the activating cation and the thioimidoyl function was suspected to be responsible for these data. Indeed, in the present study, the borderline Lewis acidic cupric cations, according to the hard and soft acid/base concept, could interact with three different centres: the exocyclic sulfur atom, the nitrogen atom and the $\mathrm{X}$ group $(\mathrm{X}=\mathrm{S}$ or $\mathrm{NH})$ of the heterocycle. A computational approach of the relative charges on atoms possibly involved in the glycosylation process gave the values summarized in Table 4. The resulting data showed that similar values were obtained for all donors $\mathbf{5 - 8}$ for $\mathrm{S}-1$, $\mathrm{N}-1$ and $\mathrm{C}-1$. On the assumption that thiophenylglycosides are not activated by cupric ions, it was expected that the exocyclic sulfur S-1 was not involved in the activation process, thus corroborating a remote activation mechanism. The main difference was however obtained for the $\mathrm{X}$ atom, because the charge on S-2 in donors 7 and $\mathbf{8}$ was significantly lower than that calculated for $\mathrm{N}-2$ in $\mathbf{5}$ and $\mathbf{6}$. We then hypothesized that a stronger interaction between $\mathrm{S}-2$ and $\mathrm{Cu}^{2+}$ was not able to really activate the furanosyl donor but may be also responsible for the observed lack of reactivity using $\mathbf{7}$ and $\mathbf{8}$.

To probe this hypothesis, two supplementary reactions were further performed (Scheme 5). Thus, the $\mathrm{Cu}^{2+}$-activated glycosylation of $n$-octanol was carried out using either thiazolinyl derivative $\mathbf{8}$ in the presence of a large excess of copper(II) triflate or donor 5 in the presence of diphenylsulfide as a scavenger of cupric cat-

Table 4. Selective data for galactofuranosyl donors 5-8

\begin{tabular}{|c|c|c|c|c|c|c|}
\hline Entry & Donor & Heterocycle & $\mathrm{C}-1$ anomeric & S-1 & $\mathrm{N}-1$ & $\mathrm{X}$ \\
\hline 1 & 5 & & 0.365 & -0.462 & -0.218 & $-0.230(\mathrm{~N}-2)$ \\
\hline 2 & 6 & & 0.348 & -0.430 & -0.274 & $-0.173(\mathrm{~N}-2)$ \\
\hline 3 & $7 \beta$ & & 0.368 & -0.405 & -0.203 & $-0.394(\mathrm{~S}-2)$ \\
\hline 4 & $8 \beta$ & $\begin{array}{l}\mathrm{s} \\
\downarrow\end{array}$ & 0.368 & -0.396 & -0.210 & $-0.385(\mathrm{~S}-2)$ \\
\hline
\end{tabular}




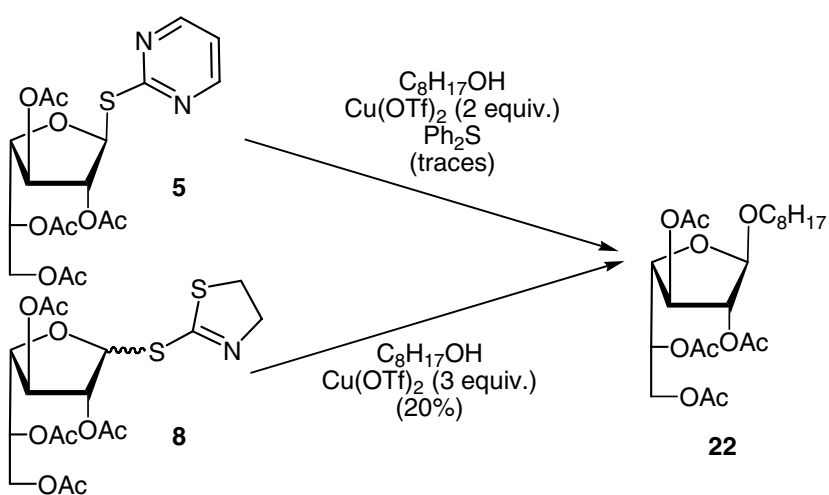

Scheme 5. Influence of additive diphenylsulfide or excess $\mathrm{Cu}(\mathrm{OTf})_{2}$ on glycosidation of $\mathbf{5}$ and $\mathbf{8}$, respectively.

ions. The resulting peracetylated octyl galactofuranoside 22 was thus isolated in moderate $20 \%$ yield, close to that obtained for $\mathbf{1 7}$ under similar conditions. However, the use of diphenylsulfide really inhibited the desired coupling since only traces of $\mathbf{2 2}$ were observed by monitoring the reaction by thin layer chromatography. This result therefore support the notion that a sulfur atom present on the heterocycle could modulate the activation of thioimidates by $\mathrm{Cu}^{2+}$.

In conclusion, the synthesis of relevant galactofuranose-containing disaccharides was achieved through the remote activation of four furanosyl thioimidates using copper(II) triflate as an activator. The large heterogeneousness of the results was first connected with the size of the glycosyl acceptors (pyranosyl vs furanosyl) and was secondly ascribed to the presence on the heterocyclic aglycon of an endocyclic sulfur atom or amino group. Better coordination of the cupric cations by this sulfur than by a nitrogen atom manifested in a lack of reactivity of the thiazole-like donors. Further studies are currently underway to investigate the potential orthogonality of these families of thioimidates in the presence of various promoters.

\section{Experimental}

\subsection{General methods}

All reactions were performed at $\mathrm{rt}$ under $\mathrm{N}_{2}$ atmosphere. Pyrimidin-2-yl 2,3,5,6-tetra- $O$-acetyl-1-thio- $\beta$-D-galactofuranoside (5), ${ }^{44}$ benzimidazol-2-yl 2,3,5,6-tetra- $O$-acetyl-1-thio- $\beta$-D-galactofuranoside $(\mathbf{6}),{ }^{44}$ benzothiazol2 -yl 2,3,5,6-tetra- $O$-acetyl-1-thio- $\beta$-D-galactofuranoside $\left(7^{44}\right.$ and octyl 2,3,5-tri- $O$-benzyl- $\beta$-D-galactofuranoside $(\mathbf{1 2})^{49}$ were synthesized as previously described. Octyl 2,3,6-tri- $O$-benzyl- $\beta$-D-galactofuranoside (13) was obtained as described by Pathak et al. ${ }^{50}$ Phenyl 2,3,4-tri$O$-benzyl-1-thio- $\alpha$-D-mannopyranoside (11) was synthesized as reported by Martín-Lomas et al. ${ }^{48}$ Methyl 2,3,4-tri- $O$-benzyl- $\alpha$-D-glucopyranoside (10) was obtained as described by Reitz et al. ${ }^{56}$ Reactions were monitored by TLC (E. Merck $60 \mathrm{~F}_{254}$ Silica Gel non activated plates) and compounds were visualized by UV-absorption and/or charring with a $5 \%$ solution of $\mathrm{H}_{2} \mathrm{SO}_{4}$ in EtOH. Preparative chromatography was conducted on Geduran Si 60 (40-63 $\mu \mathrm{m})$ Silica Gel. Melting points were determined on a Reichert microscope and are uncorrected. Optical rotations were measured on a Perkin-Elmer 341 polarimeter. ${ }^{1} \mathrm{H},{ }^{13} \mathrm{C}, \mathrm{HMBC}$, HMQC and COSY NMR spectra were recorded at the ENSCR on a Bruker ARX 400 spectrometer at $400 \mathrm{MHz}$ for ${ }^{1} \mathrm{H}$ and $100 \mathrm{MHz}$ for ${ }^{13} \mathrm{C}$ analyses. 1D and $2 \mathrm{D}$ spectra of unprotected disaccharides were recorded on a Bruker Avance 500 spectrometer at $500 \mathrm{MHz}$ for ${ }^{1} \mathrm{H}$ and $125 \mathrm{MHz}$ for ${ }^{13} \mathrm{C}$, by the 'Service de Spectrométrie de RMN Haut Champ du Centre Régional de Mesures Physiques de l'Ouest (CRMPO, Rennes, France)'. Chemical shifts are given in $\delta$ units measured from the solvent signal. The HRMS were performed at the CRMPO with a MS/MS ZabSpec TOF Micromass by ESI in positive mode. Microanalyses were performed by the 'Service de Microanalyse de l'ICSN (Gif sur Yvette, France)' and by the CRMPO.

\subsection{Thiazolin-2-yl 2,3,5,6-tetra- $O$-acetyl-1-thio-D- galactofuranoside (8)}

To a solution of 1,2,3,5,6-penta- $O$-acetyl-D-galactofuranose $(9)^{41}(2.00 \mathrm{~g}, 5.12 \mathrm{mmol})$ in $\mathrm{CH}_{2} \mathrm{Cl}_{2}(82 \mathrm{~mL})$ were added 2-mercaptothiazoline $(1.83 \mathrm{~g}, 15.37 \mathrm{mmol})$ and $\mathrm{BF}_{3} \cdot \mathrm{OEt}_{2}(5.8 \mathrm{~mL}, 46.08 \mathrm{mmol})$. The solution was stirred at $\mathrm{rt}$ for $24 \mathrm{~h}$ and was diluted with $\mathrm{CH}_{2} \mathrm{Cl}_{2}$ $(80 \mathrm{~mL})$. The reaction mixture was washed with a satd aq $\mathrm{NaHCO}_{3}(3 \times 50 \mathrm{~mL})$ and with $\mathrm{H}_{2} \mathrm{O}(3 \times 100 \mathrm{~mL})$. The aq layers thus obtained were extracted with $\mathrm{CH}_{2} \mathrm{Cl}_{2}$ $(3 \times 50 \mathrm{~mL})$ and the combined organic layers were dried $\left(\mathrm{MgSO}_{4}\right)$ and finally concentrated. Purification of the residue by column chromatography $\left(9: 1, \mathrm{CH}_{2} \mathrm{Cl}_{2-}\right.$ EtOAc) as eluent gave 8 in anomeric mixture $(\alpha / \beta=$ $1: 4.2)$ as a colourless oil $(2.15 \mathrm{~g}, 93 \%)$ : TLC (9:1, $\mathrm{CH}_{2} \mathrm{Cl}_{2}$-EtOAc): $R_{\mathrm{f}}=0.3 ; 8 \alpha:{ }^{1} \mathrm{H}$ NMR $\left(\mathrm{CDCl}_{3}\right): \delta$ $6.40\left(\mathrm{~d}, \quad 1 \mathrm{H}, \quad J_{1,2}=5.1 \mathrm{~Hz}, \mathrm{H}-1\right), \quad 5.51(\mathrm{dd}, 1 \mathrm{H}$, $\left.J_{2,3}=3.3 \mathrm{~Hz}, \quad \mathrm{H}-2\right), \quad 5.33 \quad\left(\mathrm{dt}, \quad 1 \mathrm{H}, \quad J_{4,5}=7,6 \mathrm{~Hz}\right.$, $\left.J_{5,6 \mathrm{a}}=J_{5,6 \mathrm{~b}}=4,3 \mathrm{~Hz}, \mathrm{H}-5\right), 5.23\left(\mathrm{dd}, 1 \mathrm{H}, J_{3,4}=3.8 \mathrm{~Hz}\right.$, $\mathrm{H}-3), 4.38-4.11\left(\mathrm{~m}, 5 \mathrm{H}, \mathrm{H}-4, \mathrm{H}-5 \mathrm{a}^{\prime}, \mathrm{H}-5 \mathrm{~b}^{\prime}, \mathrm{H}-6 \mathrm{a}, \mathrm{H}-\right.$ $6 \mathrm{~b}), 3.40\left(\mathrm{t}, 2 \mathrm{H},{ }^{3} \mathrm{~J}=8.0 \mathrm{~Hz}, \mathrm{H}-4 \mathrm{a}^{\prime}, \mathrm{H}-4 \mathrm{~b}^{\prime}\right), 2.15,2.13$, 2.09, $2.04\left(4 \mathrm{~s}, 12 \mathrm{H}, \mathrm{CH}_{3} \mathrm{CO}\right) ;{ }^{13} \mathrm{C}$ NMR $\left(\mathrm{CDCl}_{3}\right): \delta$ 170.6, 170.1, 169.6, 169.3 (C=O), $163.3\left(\mathrm{C}-2^{\prime}\right), 85.9(\mathrm{C}-$ 1), 81.7 (C-4), 76.4 (C-2), 76.2 (C-3), 69.5 (C-5), 64.3 (C-5'), 62.6 (C-6), 35.6 (C-4'), 21.0, 20.8, 20.7, 20.6 $\left(\mathrm{CH}_{3} \mathrm{CO}\right) ; 8$ 8及: ${ }^{1} \mathrm{H}$ NMR $\left(\mathrm{CDCl}_{3}\right): \delta 6.21-6.20(\mathrm{~m}, 1 \mathrm{H}$, $\mathrm{H}-1), 5.39\left(\mathrm{dt}, 1 \mathrm{H}, J_{4,5}=7.4 \mathrm{~Hz}, J_{5,6 \mathrm{a}}=J_{5-6 \mathrm{~b}}=4.1 \mathrm{~Hz}\right.$, H-5), 5.28 (t, $1 \mathrm{H}, J_{1,2}=J_{2,3}=1.8 \mathrm{~Hz}, \mathrm{H}-2$ ), 5.10 (ddd, $\left.1 \mathrm{H}, J_{3,4}=4.8 \mathrm{~Hz}, \mathrm{H}-3\right), 4.38-4.35(\mathrm{~m}, 1 \mathrm{H}, \mathrm{H}-4), 4.36$ $\left(\mathrm{dd}, 1 \mathrm{H}, J_{6 \mathrm{a}, 6 \mathrm{~b}}=12.0 \mathrm{~Hz}, \mathrm{H}-6 \mathrm{a}\right), 4.28,4.19(2 \mathrm{dt}, 2 \mathrm{H}$, 
$\left.{ }^{2} J=14.8 \mathrm{~Hz},{ }^{3} J=7.9 \mathrm{~Hz}, \mathrm{H}-5 \mathrm{a}^{\prime}, \mathrm{H}-5 \mathrm{~b}^{\prime}\right), 4.18(\mathrm{dd}, 1 \mathrm{H}$, H-6b), 3.40 (t, 2H, H-4a', H-4b'), 2.12, 2.12, 2.11, 2.05 $\left(4 \mathrm{~s}, 12 \mathrm{H}, \mathrm{CH}_{3} \mathrm{CO}\right) ;{ }^{13} \mathrm{C} \mathrm{NMR}\left(\mathrm{CDCl}_{3}\right): \delta 170.6,170.1$, 169.7, $169.4(\mathrm{C}=\mathrm{O}), 162.8\left(\mathrm{C}-2^{\prime}\right), 88.4(\mathrm{C}-1), 81.7$ (C-4), 80.9 (C-2), 76.4 (C-3), 69.2 (C-5), $64.3\left(\mathrm{C}-5^{\prime}\right)$, 62.6 (C-6), 35.4 (C-4'), 20.9, 20.8, 20.8, $20.7\left(\mathrm{CH}_{3} \mathrm{CO}\right)$; HRMS Calcd for $\mathrm{C}_{17} \mathrm{H}_{23} \mathrm{NaNO}_{9} \mathrm{~S}_{2} \quad[\mathrm{M}+\mathrm{Na}]^{+}$: 472.0712. Found: 472.0712; Anal. Calcd for $\mathrm{C}_{17} \mathrm{H}_{23} \mathrm{NO}_{9} \mathrm{~S}_{2}$ : C, 45.43; H, 5.16; N, 3.12. Found: C, $45.09 ; \mathrm{H}, 5.15 ; \mathrm{N}, 3.16$.

\subsection{General procedure A: glycosylation reactions}

To a solution of thioimidoyl galactofuranoside $(0.23 \mathrm{mmol})$ in $\mathrm{CH}_{2} \mathrm{Cl}_{2}(10 \mathrm{~mL} / \mathrm{g})$ were successively added the appropriate acceptor $(0.12 \mathrm{mmol}$ or $0.46 \mathrm{mmol}$; depending on the acceptor $)$ and $\mathrm{Cu}(\mathrm{OTf})_{2}$ (163 $\mathrm{mg}, 0.45 \mathrm{mmol}$ ). The mixture was stirred at $\mathrm{rt}$ for a given period and the reaction was quenched by addition of a few drops of $\mathrm{Et}_{3} \mathrm{~N}$. Insoluble materials were removed by filtration and the filtrate was concentrated to dryness. The residue thus obtained was then purified by chromatography on silica gel. The fractions containing the target protected disaccharide were pooled, concentrated under reduced pressure and diluted in dry $\mathrm{MeOH}$ $(20 \mathrm{~mL})$. A $0.1 \mathrm{M}$ solution of $\mathrm{NaOMe}$ in $\mathrm{MeOH}$ $(2.3 \mathrm{~mL}, 0.23 \mathrm{mmol})$ was then added and the mixture was stirred at $\mathrm{rt}$ overnight. The reaction was quenched by adding a few drops of $\mathrm{AcOH}$ and the solution was concentrated under reduced pressure. The partially deprotected disaccharide was finally recovered by chromatographic purification.

\subsection{Methyl $\beta$-D-galactofuranosyl-( $(\rightarrow 6)-2,3,4$-tri- $O$ - benzyl- $\alpha$-D-glucopyranoside (17)}

This compound was produced according to the general procedure A from the pyrimidin-2-yl galactofuranoside $5(226 \mathrm{mg}, 0.51 \mathrm{mmol})$ and from the glucopyranoside acceptor 10 (119 mg, $0.26 \mathrm{mmol})$. After stirring for $2 \mathrm{~h}$ and work-up, the resulting disaccharide was purified by chromatography using $3: 2$, light petroleum-EtOAc as eluant [TLC (3:2, light petroleum-EtOAc): $\left.R_{\mathrm{f}}=0.4\right]$. The mixture thus obtained was deacetylated as described. The partially deprotected disaccharide $\mathbf{1 7}$ was purified by chromatography $\left(19: 1, \mathrm{CH}_{2} \mathrm{Cl}_{2}-\mathrm{MeOH}\right)$ and was then isolated as a white solid (124 mg, 77\%): $\mathrm{mp}$ $98^{\circ} \mathrm{C}\left(\mathrm{CH}_{2} \mathrm{Cl}_{2}-\mathrm{MeOH}\right) ;[\alpha]_{\mathrm{D}}^{20}-1.0(c 1.1, \mathrm{MeOH}) ; \mathrm{TLC}$ (19:1, $\left.\mathrm{CH}_{2} \mathrm{Cl}_{2}-\mathrm{MeOH}\right): R_{\mathrm{f}}=0.1 ;{ }^{1} \mathrm{H}$ NMR $\left(\mathrm{CD}_{3} \mathrm{OD}\right): \delta$ 7.38-7.24 (m, 15H, $\left.\mathrm{C}_{6} \mathrm{H}_{5}\right), 4.92-4.62\left(\mathrm{~m}, 6 \mathrm{H}, \mathrm{OCH}_{2} \mathrm{Ph}\right)$, $4.87\left(\mathrm{~d}, 1 \mathrm{H}, \quad J_{1^{\prime}, 2^{\prime}}=1.8 \mathrm{~Hz}, \mathrm{H}-1^{\prime}\right), 4.71(\mathrm{~d}, 1 \mathrm{H}$, $\left.J_{1,2}=3.6 \mathrm{~Hz}, \quad \mathrm{H}-1\right), 4.00\left(\mathrm{dd}, 1 \mathrm{H}, \quad J_{3^{\prime}, 4^{\prime}}=6.4 \mathrm{~Hz}\right.$, $\left.J_{2^{\prime}, 3^{\prime}}=0.8 \mathrm{~Hz}, \mathrm{H}-3^{\prime}\right), 3.97\left(\mathrm{dd}, 1 \mathrm{H}, \mathrm{H}-2^{\prime}\right), 3.94(\mathrm{dd}$, $\left.1 \mathrm{H}, J_{4^{\prime}, 5^{\prime}}=3.1 \mathrm{~Hz}, \mathrm{H}-4^{\prime}\right), 3.92\left(\mathrm{dd}, 1 \mathrm{H}, J_{6 \mathrm{a}, 6 \mathrm{~b}}=11.2 \mathrm{~Hz}\right.$, $\left.J_{5,6 \mathrm{a}}=1.8 \mathrm{~Hz}, \quad \mathrm{H}-6 \mathrm{a}\right), 3.87\left(\mathrm{dd}, 1 \mathrm{H}, \quad J_{2,3}=9.4 \mathrm{~Hz}\right.$, $\left.J_{3,4}=9.2 \mathrm{~Hz}, \mathrm{H}-3\right), 3.74-3.69\left(\mathrm{~m}, 2 \mathrm{H}, \mathrm{H}-5, \mathrm{H}-5^{\prime}\right)$,
3.62-3.57 (m, 3H, H-6b, H-6a', H-6b'), $3.54(\mathrm{dd}, 1 \mathrm{H}$, $\mathrm{H}-2), 3.51\left(\mathrm{dd}, 1 \mathrm{H}, J_{4,5}=9.9 \mathrm{~Hz}, \mathrm{H}-4\right), 3.38(\mathrm{~s}, 3 \mathrm{H}$, $\left.\mathrm{OCH}_{3}\right) ;{ }^{13} \mathrm{C}$ NMR $\left(\mathrm{CD}_{3} \mathrm{OD}\right): \delta 140.1,139.7,139.6$ $\left(\mathrm{C}_{\mathrm{ipso}}\right), 129.5,129.4,129.3,129.2,129.0,128.9,128.7$, $128.6\left(\mathrm{C}_{6} \mathrm{H}_{5}\right), 109.8\left(\mathrm{C}-1^{\prime}\right), 99.1(\mathrm{C}-1), 84.3\left(\mathrm{C}-4^{\prime}\right), 83.2$ (C-2'), 83.0 (C-3), 81.4 (C-2), 79.0 (C-4), 78.6 (C-3'), 76.5, 76.0, $74.0\left(\mathrm{OCH}_{2} \mathrm{Ph}\right), 72.3\left(\mathrm{C}-5^{\prime}\right), 71.5(\mathrm{C}-5), 67.6$ (C-6), $64.6\left(\mathrm{C}-6^{\prime}\right), 55.6\left(\mathrm{OCH}_{3}\right)$; HRMS Calcd for $\mathrm{C}_{34} \mathrm{H}_{42} \mathrm{KO}_{11}[\mathrm{M}+\mathrm{K}]^{+}$: 665.2364. Found: 665.2365.

\subsection{Phenyl $\beta$-D-galactofuranosyl-( $1 \rightarrow 6)-2,3,4-$ tri- $O$ -

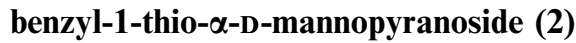

This disaccharide was obtained according to the general procedure A from the thiogalactofuranoside $5(68 \mathrm{mg}$, $0.15 \mathrm{mmol}$ ) and the mannopyranosidic acceptor $\mathbf{1 1}$ (168 $\mathrm{mg}, 0.31 \mathrm{mmol})$. The acetylated intermediate 19 was purified by chromatography $(4: 1 \rightarrow 3: 2$, light petroleum-EtOAc). The fractions containing this product [TLC (4:1, light petroleum-EtOAc): $\left.R_{\mathrm{f}}=0.1\right]$ were pooled, concentrated and subjected to Zémplen deacetylation. The disaccharide $\mathbf{2}$ thus generated was purified by flash chromatography $\left(19: 1, \mathrm{CH}_{2} \mathrm{Cl}_{2}-\mathrm{MeOH}\right)$. This compound was then isolated as a colourless oil $(65 \mathrm{mg}$, $60 \%):[\alpha]_{\mathrm{D}}^{20}+30.2(c 1.0, \mathrm{MeOH}) ; \operatorname{TLC}\left(19: 1, \mathrm{CH}_{2} \mathrm{Cl}_{2}-\right.$ $\mathrm{MeOH}): R_{\mathrm{f}}=0.2 ;{ }^{1} \mathrm{H}$ NMR $\left(\mathrm{CD}_{3} \mathrm{OD}\right): \delta 7.48-7.45$, $7.39-7.26\left(2 \mathrm{~m}, 20 \mathrm{H}, \mathrm{C}_{6} \mathrm{H}_{5}\right), 5.47\left(\mathrm{~d}, 1 \mathrm{H}, J_{1,2}=1.5 \mathrm{~Hz}\right.$, $\mathrm{H}-1), 4.91-4.86,4.70-4.54\left(2 \mathrm{~m}, 6 \mathrm{H}, \mathrm{OCH}_{2} \mathrm{Ph}\right), 4.87$ $4.86\left(\mathrm{~m}, 1 \mathrm{H}, \mathrm{H}-1^{\prime}\right), 4.20\left(\mathrm{ddd}, 1 \mathrm{H}, J_{5,6 \mathrm{~b}}=5.6 \mathrm{~Hz}\right.$, $\left.J_{5,6 \mathrm{a}}=1.8 \mathrm{~Hz}, \mathrm{H}-5\right), 4.05\left(\mathrm{dd}, 1 \mathrm{H}, J_{2,3}=3.0 \mathrm{~Hz}, \mathrm{H}-2\right)$, 4.00-3.94 (m, 2H, H-2', H-3'), 3.96-3.92 (m, 2H, H-4', H-6a), $3.92\left(\mathrm{dd}, 1 \mathrm{H}, J_{4,5}=9.6 \mathrm{~Hz}, \mathrm{H}-4\right), 3.82(\mathrm{dd}$, $\left.1 \mathrm{H}, \quad J_{3,4}=9.2 \mathrm{~Hz}, \quad \mathrm{H}-3\right), \quad 3.70 \quad\left(\mathrm{ddd}, \quad 1 \mathrm{H}, \quad J_{5^{\prime}, 6 \mathrm{a}^{\prime}}=\right.$ $\left.J_{51,6 \mathrm{~b}^{\prime}}=6.1 \mathrm{~Hz}, J_{4^{\prime}, 5^{\prime}}=3.0 \mathrm{~Hz}, \mathrm{H}-5^{\prime}\right), 3.64(\mathrm{dd}, 1 \mathrm{H}$, $\left.J_{6 \mathrm{a}, 6 \mathrm{~b}}=11.2 \mathrm{~Hz}, \mathrm{H}-6 \mathrm{~b}\right), 3.60-3.57\left(\mathrm{~m}, 2 \mathrm{H}, \mathrm{H}-6 \mathrm{a}^{\prime}, \mathrm{H}-\right.$ $\left.6 \mathrm{~b}^{\prime}\right) ;{ }^{13} \mathrm{C}$ NMR $\left(\mathrm{CD}_{3} \mathrm{OD}\right): \delta 139.8,139.4,139.3\left(\mathrm{C}_{\text {ipso }}\right.$ $\left.\mathrm{OCH}_{2} \mathrm{Ph}\right), 135.4\left(\mathrm{C}_{\text {ipso }} \mathrm{SPh}\right), 133.3,130.2,129.5,129.4$, $129.2,129.2,129.0,128.9,128.8,128.8\left(\mathrm{C}_{6} \mathrm{H}_{5}\right), 109.6$ (C-1'), 87.3 (C-1), 84.7 (C-4'), $83.0\left(\mathrm{C}-2^{\prime}\right), 81.0$ (C-3), $79.0\left(\mathrm{C}-3^{\prime}\right), 77.4(\mathrm{C}-2), 76.1,73.2,72.9\left(\mathrm{OCH}_{2} \mathrm{Ph}\right), 75.9$ (C-4), 73.7 (C-5), 72.4 (C-5'), 67.5 (C-6), 64.7 (C-6'); HRMS Calcd for $\mathrm{C}_{39} \mathrm{H}_{44} \mathrm{NaO}_{10} \mathrm{~S}[\mathrm{M}+\mathrm{Na}]^{+}: 727.2553$. Found: 723.2550 .

\subsection{Octyl $\beta$-D-galactofuranosyl-( $(\rightarrow 6)-2,3,5$-tri- $O$-benz- yl- $\beta$-D-galactofuranoside (20)}

The disaccharide $\mathbf{2 0}$ was synthesized according the general procedure A from thioimidoyl galactofuranoside $\mathbf{5}$ (181 $\mathrm{mg}, 0.41 \mathrm{mmol}$ ) and the galactofuranosidic acceptor $12(459 \mathrm{mg}, 0.82 \mathrm{mmol})$. The acetylated intermediate was then purified by flash chromatography $(4: 1 \rightarrow 3: 2$, light petroleum-EtOAc) [TLC (4:1, light petroleumEtOAc): $\left.R_{\mathrm{f}}=0.4\right]$. The resulting crude oil was further deacetylated as described. The partially benzylated disaccharide $\mathbf{2 0}$ was purified by chromatography on sil- 
ica gel eluting with 19:1, $\mathrm{CH}_{2} \mathrm{Cl}_{2}-\mathrm{MeOH}$, and was then isolated as a colourless oil $(88 \mathrm{mg}, 30 \%):[\alpha]_{\mathrm{D}}^{20}-81.3(c$ 1.4, $\mathrm{MeOH}) ; \operatorname{TLC}\left(19: 1, \mathrm{CH}_{2} \mathrm{Cl}_{2}-\mathrm{MeOH}\right): R_{\mathrm{f}}=0.2$; ${ }^{1} \mathrm{H}$ and ${ }^{13} \mathrm{C}$ NMR spectra were identical to the reported data; ${ }^{50}$ HRMS Calcd for $\mathrm{C}_{41} \mathrm{H}_{56} \mathrm{NaO}_{11} \quad[\mathrm{M}+\mathrm{Na}]^{+}$: 747.3720. Found: 747.3721.

\subsection{Octyl $\beta$-D-galactofuranosyl-( $1 \rightarrow 5)-2,3,5$-tri- $O$-benz- yl- $\beta$-D-galactofuranoside (21)}

This compound was obtained as described in procedure A from the galactofuranosidic donor $5(220 \mathrm{mg}$, $0.50 \mathrm{mmol})$ and the acceptor $13(137 \mathrm{mg}, 0.24 \mathrm{mmol})$. The partially acetylated disaccharide was then isolated by chromatographic purification (4:1, light petroleumEtOAc) [TLC (7:3, light petroleum-EtOAc): $R_{\mathrm{f}}=0.3$ ] and the fractions containing this product were combined, concentrated and subjected to Zemplen transesterification. The disaccharide $\mathbf{2 1}$ was purified by chromatography on silica gel (19:1, $\left.\mathrm{CH}_{2} \mathrm{Cl}_{2}-\mathrm{MeOH}\right)$ and could be finally isolated as a colourless oil $(24 \mathrm{mg}$, 14\%): $[\alpha]_{\mathrm{D}}^{20}-60.9$ (c 1.0, MeOH); TLC (19:1, $\mathrm{CH}_{2} \mathrm{Cl}_{2^{-}}$ $\mathrm{MeOH}): R_{\mathrm{f}}=0.2 ;{ }^{1} \mathrm{H}$ and ${ }^{13} \mathrm{C}$ NMR spectra were identical to the reported data; ${ }^{50}$ HRMS Calcd for $\mathrm{C}_{41} \mathrm{H}_{56} \mathrm{NaO}_{11}[\mathrm{M}+\mathrm{Na}]^{+}$: 747.3720. Found: 747.3726.

\subsection{General procedure B: debenzylation reactions}

$\mathrm{AcOH}(2.5 \mathrm{~mL})$ and $\mathrm{Pd}(\mathrm{OAc})_{2}(5 \mathrm{mg})$ were added to a solution of disaccharide $(30 \mathrm{mg})$ in EtOAc $(2.5 \mathrm{~mL})$. After stirring under hydrogen $(1 \mathrm{~atm})$ at $\mathrm{rt}$ for $72 \mathrm{~h}$, the mixture was filtered, concentrated under reduced pressure and traces of $\mathrm{AcOH}$ were coevaporated with toluene $(5 \times 5 \mathrm{~mL})$. The totally unprotected disaccharide was then isolated by flash chromatography on silica gel.

\subsection{Methyl $\beta$-D-galactofuranosyl-( $(1 \rightarrow 6)-\alpha$-D-glucopyr- anoside (1)}

This compound was synthesized according to the general procedure $\mathrm{B}$ from the benzylated disaccharide $\mathbf{1 7}$ ( $31 \mathrm{mg}, 0.05 \mathrm{mmol}$ ). The target product 1 was then purified by chromatography on silica gel (3:3:1, EtOAc$i$-PrOH$-\mathrm{H}_{2} \mathrm{O}$ ), and was isolated as a colourless hygroscopic foam $(17 \mathrm{mg}, 97 \%)$ : $[\alpha]_{\mathrm{D}}^{20}+13.7\left(c 0.3, \mathrm{H}_{2} \mathrm{O}\right)$; TLC (3:3:1, EtOAc- $i$-PrOH- $\left.\mathrm{H}_{2} \mathrm{O}\right): R_{\mathrm{f}}=0.4 ;{ }^{1} \mathrm{H}$ NMR $\left(\mathrm{D}_{2} \mathrm{O}\right): \delta 4.95\left(\mathrm{~d}, 1 \mathrm{H}, J_{1^{\prime}, 2^{\prime}}=1.8 \mathrm{~Hz}, \mathrm{H}-1^{\prime}\right), 4.72$ $\left(\mathrm{d}, 1 \mathrm{H}, J_{1,2}=3.8 \mathrm{~Hz}, \mathrm{H}-1\right), 4.03\left(\mathrm{dd}, 1 \mathrm{H}, J_{2^{\prime}, 3^{\prime}}=\right.$ $\left.3.9 \mathrm{~Hz}, \mathrm{H}-2^{\prime}\right), 3.99\left(\mathrm{dd}, 1 \mathrm{H}, J_{3^{\prime}, 4^{\prime}}=6.6 \mathrm{~Hz}, \mathrm{H}-3^{\prime}\right), 3.93$ $\left(\mathrm{dd}, \quad 1 \mathrm{H}, \quad J_{6 \mathrm{a}, 6 \mathrm{~b}}=11.0 \mathrm{~Hz}, \quad J_{5,6 \mathrm{a}}=1.4 \mathrm{~Hz}, \quad \mathrm{H}-6 \mathrm{a}\right)$, $3.91\left(\mathrm{dd}, 1 \mathrm{H}, J_{4^{\prime} .5^{\prime}}=4.1 \mathrm{~Hz}, \mathrm{H}-4^{\prime}\right), 3.75(\mathrm{ddd}, 1 \mathrm{H}$, $\left.J_{5^{\prime}, 6 \mathrm{~b}^{\prime}}=7.3 \mathrm{~Hz}, \quad J_{5^{\prime}, 6 \mathrm{a}^{\prime}}=4.3 \mathrm{~Hz}, \quad \mathrm{H}-5^{\prime}\right), \quad 3.70 \quad(\mathrm{ddd}$, $\left.1 \mathrm{H}, J_{4,5}=9.3 \mathrm{~Hz}, J_{5,6 \mathrm{~b}}=5.4 \mathrm{~Hz}, \mathrm{H}-5\right), 3.66(\mathrm{dd}, 1 \mathrm{H}$, $\mathrm{H}-6 \mathrm{~b}), 3.64\left(\mathrm{dd}, 1 \mathrm{H}, J_{6 \mathrm{a}^{\prime}, 6 \mathrm{~b}^{\prime}}=11.7 \mathrm{~Hz}, \mathrm{H}-6 \mathrm{a}^{\prime}\right), 3.59$ $\left(\mathrm{dd}, 1 \mathrm{H}, J_{2,3}=9.8 \mathrm{~Hz}, J_{3,4}=9.3 \mathrm{~Hz}, \mathrm{H}-3\right), 3.58(\mathrm{dd}$, $1 \mathrm{H}, \mathrm{H}-6 \mathrm{~b}^{\prime}$ ), 3.49 (dd, 1H, H-2), 3.37 (t, 1H, H-4), 3.34 $\left(\mathrm{s}, 1 \mathrm{H}, \mathrm{OCH}_{3}\right) ;{ }^{13} \mathrm{C} \mathrm{NMR}\left(\mathrm{D}_{2} \mathrm{O}\right): \delta 107.9\left(\mathrm{C}-1^{\prime}\right), 99.3$ (C-1), $82.6\left(\mathrm{C}-4^{\prime}\right), 81.0\left(\mathrm{C}-2^{\prime}\right), 76.6\left(\mathrm{C}-3^{\prime}\right), 73.0(\mathrm{C}-3)$, 71.1 (C-2), 70.7 (C-5'), 70.6 (C-5), 69.5 (C-4), 66.7 (C6), $62.7\left(\mathrm{C}-6^{\prime}\right), 55.2\left(\mathrm{OCH}_{3}\right)$; HRMS Calcd for $\mathrm{C}_{13} \mathrm{H}_{24} \mathrm{NaO}_{11}[\mathrm{M}+\mathrm{Na}]^{+}: 379.1216$. Found: 379.1219.

\subsection{Octyl $\beta$-D-galactofuranosyl-( $1 \rightarrow 6)-\beta$-D-galactofur- anoside (3)}

The unprotected disaccharide $\mathbf{3}$ could be obtained according the general procedure $\mathrm{B}$ from the partially benzylated disaccharide 21 (67 $\mathrm{mg}, 0.09 \mathrm{mmol})$. The target glycoconjugate 3 could then be isolated after chromatographic purification using 19:1, $\mathrm{CH}_{2} \mathrm{Cl}_{2}-\mathrm{MeOH}$ as eluent, as a colourless oil $(28 \mathrm{mg}, 67 \%):[\alpha]_{\mathrm{D}}^{20}+12.6$ (c 1.5, $\left.\mathrm{H}_{2} \mathrm{O}\right)$; TLC $\left(19: 1, \mathrm{CH}_{2} \mathrm{Cl}_{2}-\mathrm{MeOH}\right): R_{\mathrm{f}}=0.3$; ${ }^{1} \mathrm{H}$ and ${ }^{13} \mathrm{C}$ NMR spectra were identical to the reported data; ${ }^{49,50}$ HRMS Calcd for $\mathrm{C}_{20} \mathrm{H}_{38} \mathrm{NaO}_{11}[\mathrm{M}+\mathrm{Na}]^{+}$: 477.2312. Found: 477.2292.

\subsection{Calculations of the charges}

Hyperchem Molecular Visualization and Simulation software (Hypercube, Waterloo, Ontario, Canada, software HyperChem 7.5) was used to calculate the charges on the interesting atoms. The initial geometries of the compounds 5-8 were built by means of standard parameters, applying an Amber molecular mechanics force field and then optimized by TNDO geometrical optimization. The resulting charge values were not considered individually but were rather used to make comparisons between similar species. Selected data are summarized in Table 4.

\section{Acknowledgements}

We are grateful to the French Ministry of Education, Research and Technology for a grant to R.E. We also thank Martine Lefeuvre and Jean-Paul Guégan (ENSCR) for recording NMR spectra. Finally, we are grateful to Richard Daniellou (ENSCR) and Jean-Louis Reymond (University of Bern) for helpful discussions.

\section{References}

1. McConville, M. J.; Homans, S. W.; Thomas-Oates, J. E.; Dell, A.; Bacic, A. J. Biol. Chem. 1990, 265, 7385-7394.

2. Sprott, G. D. J. Bioenerg. Biomembr. 1992, 24, 555-566.

3. Koga, Y.; Nishihara, M.; Morri, H.; Akagawa-Matsushita, M. Microbiol. Rev. 1993, 57, 164-182.

4. de Lederkremer, R. M.; Colli, W. Glycobiology 1995, 5, 547-552.

5. Green, J. W. Adv. Carbohydr. Chem. 1966, 21, 95-142. 
6. Joe, M.; Sun, D.; Taha, H.; Completo, G. C.; Croudace, J. E.; Lammas, D. A.; Besra, G. S.; Lowary, T. L. J. Am. Chem. Soc. 2006, 128, 5059-5072.

7. Hederos, M.; Konradsson, P. J. Am. Chem. Soc. 2006, $128,3414-3419$.

8. Gandolfi-Donadio, L.; Gallo-Rodriguez, C.; de Lederkremer, R. M. Can. J. Chem. 2006, 84, 486-491.

9. Gelin, M.; Ferrières, V.; Lefeuvre, M.; Plusquellec, D. Eur. J. Org. Chem. 2003, 1285-1293.

10. Gelin, M.; Ferrières, V.; Plusquellec, D. Eur. J. Org. Chem. 2000, 1423-1431.

11. Ferrières, V.; Roussel, M.; Gelin, M.; Plusquellec, D. J. Carbohydr. Chem. 2001, 20, 855-865.

12. McAuliffe, J. C.; Hindsgaul, O. J. Org. Chem. 1997, 62, 1234-1239.

13. Choudhury, A. K.; Roy, N. Carbohydr. Res. 1998, 308, 207-211.

14. Marino, C.; Chiocconi, A.; Varela, O.; de Lederkremer, R. M. Carbohydr. Res. 1998, 311, 183-189.

15. Sarkar, S. K.; Kumar, C. A.; Mukhopadhyay, B.; Roy, N. J. Carbohydr. Chem. 1999, 18, 1121-1130.

16. Kerr, A.; Htay, H. Physiol. Plant Pathol. 1974, 4, 3744.

17. Chaves das Neves, H. J.; Pais, M. S. S. Tetrahedron Lett. 1980, 21, 4387-4390.

18. Park, M. K.; H., P. J.; Shin, Y. G.; Kim, W. Y.; Lee, J. H.; Kim, K. H. Planta Med. 1996, 62, 363-365.

19. Mićović, V. M.; Hranisavljević, M.; Miljković-Stojanović, J. Carbohydr. Res. 1969, 10, 525-533.

20. Gerwig, G. J.; Kamerling, J. P.; Vliegenthart, J. F. G.; Morag-Morgenstern, E.; Lamed, R.; Bayer, E. A. Eur. J. Biochem. 1992, 205, 799-808.

21. Pettit, G. R.; Xu, J. P.; Gingrich, D. E.; Williams, M. D.; Doubek, D. L.; Chapuis, J. C.; Schmidt, J. M. Chem. Commun. 1999, 915-916.

22. Domenech, J.; Prieto, A.; Barasoain, I.; Gómez-Miranda, B.; Bernabé, M.; Leal, J. A. Microbiology 1999, 145, 27892796.

23. Molinaro, A.; Piscopo, V.; Lanzetta, R.; Parrilli, M. Carbohydr. Res. 2002, 337, 1707-1713.

24. Stevenson, G.; Neal, B.; Liu, D.; Hobbs, M.; Packer, N. H.; Batley, M.; Redmond, J. W.; Lindquist, L.; Reeves, P. J. Bacteriol. 1994, 176, 4144-4156.

25. Germond, J. E.; Delley, M.; D’Amico, N.; Vincent, S. J. F. Eur. J. Biochem. 2001, 268, 5149-5156.

26. Linnerborg, M.; Weintraub, A.; Widmalm, G. Eur. J. Biochem. 1999, 266, 460-466.

27. Eserstam, R.; Rajaguru, T. P.; Jansson, P. E.; Weintraub, A.; Albert, M. J. Eur. J. Biochem. 2002, 269, 32893295 .

28. Tzianabos, A.; Wang, J. Y.; Kasper, D. L. Carbohydr. Res. 2003, 338, 2531-2538.

29. Jones, C.; Todeschini, A. R.; Agrellos, O. A.; Previato, J. O.; Mendonça-Previato, L. Biochemistry 2004, 43, 1188911897.

30. Besra, G. S.; Khoo, K. H.; McNeil, M. R.; Dell, A.; Morris, H. R.; Brennan, P. J. Biochemistry 1995, 34, 42574266 .
31. Brennan, P. J.; Nikaido, H. Annu. Rev. Biochem. 1995, 64, 29-63.

32. Czaja, J.; Jachymek, W.; Niedziela, T.; Lugowski, C.; Aldova, E.; Kenne, L. Eur. J. Biochem. 2000, 267, 16721679 .

33. Zdorovenko, E. L.; Ovod, V. V.; Zatonsky, G. V.; Shashkov, A. S.; Kocharova, N. A.; Knirel, Y. A. Carbohydr. Res. 2001, 330, 505-510.

34. Sørum, U.; Robertsen, B.; Kenne, L. Carbohydr. Res. 1998, 306, 305-314.

35. Perry, M. B.; MacLean, L. L. Carbohydr. Res. 2004, 339 , 1399-1402.

36. Levery, S. B.; Toledo, M. S.; Suzuki, E.; Salyan, M. E. K.; Hakomori, S. I.; Straus, A. H.; Takahashi, H. K. Biochem. Biophys. Res. Commun. 1996, 222, 639-645.

37. Hanessian, S.; Bacquet, C.; Lehong, N. Carbohydr. Res. 1980, 80, C17-C22.

38. Mukaiyama, T.; Nakatsuta, T.; Shoda, S. I. Chem. Lett. 1979, 487-490.

39. De Meo, C.; Parker, O. Tetrahedron: Asymmetry 2005, 16 , 303-307.

40. Pornsuriyasak, P.; Demchenko, A. V. Tetrahedron: Asymmetry 2005, 16, 433-439.

41. Ferrières, V.; Gelin, M.; Boulch, R.; Toupet, L.; Plusquellec, D. Carbohydr. Res. 1998, 314, 79-83.

42. Ferrier, R. J.; Furneaux, R. H. Carbohydr. Res. 1976, 52, 63-68.

43. Ferrières, V.; Blanchard, S.; Fischer, D.; Plusquellec, D. Bioorg. Med. Chem. Lett. 2002, 12, 3515-3518.

44. Euzen, R.; Ferrières, V.; Plusquellec, D. J. Org. Chem. 2005, 70, 847-855.

45. Demchenko, A. V. Curr. Org. Chem. 2003, 7, 35-79.

46. Demchenko, A. V.; Malysheva, N. N.; De Meo, C. Org. Lett. 2003, 5, 455-458.

47. Chang, C. W. T.; Chen, X. H.; Liu, H. W. J. Am. Chem. Soc. 1998, 120, 9698-9699.

48. Martín-Lomas, M.; Khiar, N.; García, S.; Koessler, J. L.; Nieto, P. M.; Rademacher, T. W. Chem. Eur. J. 2000, 6 , 3608-3621.

49. Velty, R.; Benvegnu, T.; Gelin, M.; Privat, E.; Plusquellec, D. Carbohydr. Res. 1997, 299, 7-14.

50. Pathak, A. K.; Pathak, V.; Seitz, L.; Maddry, J. A.; Gurcha, S. S.; Besra, G. S.; Suling, W. J.; Reynolds, R. C. Bioorg. Med. Chem. 2001, 9, 3129-3143.

51. Ferrières, V.; Bertho, J. N.; Plusquellec, D. Tetrahedron Lett. 1995, 36, 2749-2752.

52. Ferrières, V.; Bertho, J. N.; Plusquellec, D. Carbohydr. Res. 1998, 311, 25-35.

53. Euzen, R.; Lopez, G.; Nugier-Chauvin, C.; Ferrières, V.; Plusquellec, D.; Rémond, C.; O’Donohue, M. J. Eur. J. Org. Chem. 2005, 4860-4869.

54. Hernandez, O.; Chaudhary, S. K.; Cox, R. H.; Poter, J. Tetrahedron Lett. 1981, 22, 1491-1494.

55. Smoot, J. T.; Pornsuriyasak, P.; Demchenko, A. V. Angew. Chem., Int. Ed. 2005, 44, 7123-7126.

56. Reitz, A. B.; Tuman, R. W.; Marchione, C. S.; Jordan, A. D.; Bowden, C. R.; Maryanoff, B. E. J. Med. Chem. 1989 , $32,2110-2116$. 